\title{
MEASUREMENT OF TURBULENCE IN WIND TUNNEL WITH SCREENS
}

\author{
Peter GASPAROVIC*, Stanislav FABRY, Ladislav FOZO, Michal HOVANEC, Karol \\ SEMRAD \\ Technical University of Kosice, Department of aeronautical engineering, Slovak Republic \\ *Corresponding author. E-mail: peter.gasparovic@ @uke.sk
}

\begin{abstract}
Turbulence in wind tunnel is measured by two methods - by the measurement of aerodynamic drag of sphere and by the hot-wire CTA measurement of turbulent fluctuations. Measurements are compared with the prediction of turbulence for various configurations of screens.
\end{abstract}

Keywords: wind tunnel; turbulence measurement; turbulent sphere; CTA; hot-wire probe

\section{NOMENCLATURE}

$\mathrm{C}_{\mathrm{D}}$ - coefficient of aerodynamic drag, the drag force divided by dynamic pressure and crossection area of sphere,

Re - Reynolds number,

$\mathrm{Re}_{\text {crit }}$ - critical $\mathrm{Re}$, where the $\mathrm{C}_{\mathrm{D}}$ or other parameter abruptly changes its value,

I - turbulence intensity, ratio of root of mean square fluctuation of the velocity to average velocity $(\%)$,

TF - turbulence factor, ratio of $\mathrm{Re}_{\text {crit }}$ in free stream and $\mathrm{Re}_{\text {crit }}$ in evaluated wind tunnel (for drag of a sphere, free stream $\operatorname{Re}_{\text {crit }}=385000$ ).

\section{INTRODUCTION}

The air flow quality (e.g. in wind tunnel) is evaluated by the turbulence level. It is important to know the level of turbulence fluctuations in both the free atmosphere and the artificial air flow (in wind-tunnel) and magnitude of its effect on measured aerodynamic forces. The flow quality in the test section of wind-tunnel can be improved by insertion of honeycomb and screens in the settling chamber of wind-tunnel.

The aim is to compare the agreement between turbulence levels measured by two independent experimental methods. The turbulence level is expressed in the values of the turbulence intensity and the turbulent factor. The effect of screens on decrease of turbulence level is expressed in the value of turbulence reduction coefficient.

The first method is based on measurement of aerodynamic drag of sphere (turbulent sphere) and the second method is based on slow hot-wire. Today it is believed that the sphere is obsolete method for determination of turbulence properties, and the technology of the first option for this task is hotwire anemometry, in its CTA variant (which means Constant Temperature Anemometry).

However, the method with sphere is cheaper and more accessible for small school projects, therefore this paper aims at finding out what exactly are the limits and drawbacks of this method. The most important publications on measurement of turbulence by sphere are [1-9]. The measured data are mainly taken from the master thesis [10].

Examples of difficulties in aerodynamic measurements caused by effects of turbulence are described in $[11,12]$. The standard methods and instrumentation for measurement of air speed are described in [13-16].

Description of details during the development of accurate pressure probes and modeling of inviscid flow past sphere are shown in [17-19]. 
Preliminary results of comparison of both methods were presented in [20] and [21].

\section{TURBULENCE}

The exact definition what exactly the turbulence is, depends on specific situation. For example, the motion of large eddies in meteorologic scale doesn't have effect on transition on boundary layer of small object therefore we don't count it as a turbulence in the case of sphere. Dryden [7] advised to count only the flow fluctuations during the time interval of $10 \mathrm{x}$ longitudinal size of object / velocity. The changes of the wind with longer periods are not considered as turbulence.

The main statistical properties of the turbulence, which determine its effect on the flow in boundary layer of sphere are turbulent intensity I, and turbulent length scale L.

Turbulent intensity is defined as a ratio of root of mean square fluctuation of the velocity to average velocity.

\section{WIND-TUNNEL}

The measurements are done in the large low-speed wind tunnel of the Faculty of Aeronautics of the Technical University in Košice. It is a low-speed 1x0.5m wind-tunnel (on Fig. 1), designed in 1955 by Miroslav Kryl during his stay in military aviation vocational school in Liptovsky Mikulas. The design copied the layout of similar tunnel in VZLU Praha. The propeller was manufactured in the Avia company. Later, the tunnel was installed in campus of air force academy in Kosice, and at that state it was used from 1981 till 2019. In the august, the old faulty thyristor speed controller, manufactured by ZPA Presov, was replaced with the new electronic controller manufactured by Ing. Sivy.

The wind-tunnel is of Gottingen scheme, test section is oval cross-section $1 \times 0.5 \mathrm{~m}$, diffuser angle $5.9-6.3^{\circ}$ between opposite walls, contraction ratio 3.9 and max. velocity with empty test section is $44.4 \mathrm{~m} / \mathrm{s}$. Instrumentation is a manually operated three-component mechanical balance by the design of Václav Smolař and Jiří Krejčí, located above test section.

The wind-tunnel was not equipped with screens. It has only very crude honeycomb. It was used mainly for demonstration of various aerodynamic phenomena to the cadets of air force academy and later public university. Because of doubts about turbulence properties its use for research projects was limited to simple flows with well-defined separation flows and pressure probes with attached flow.

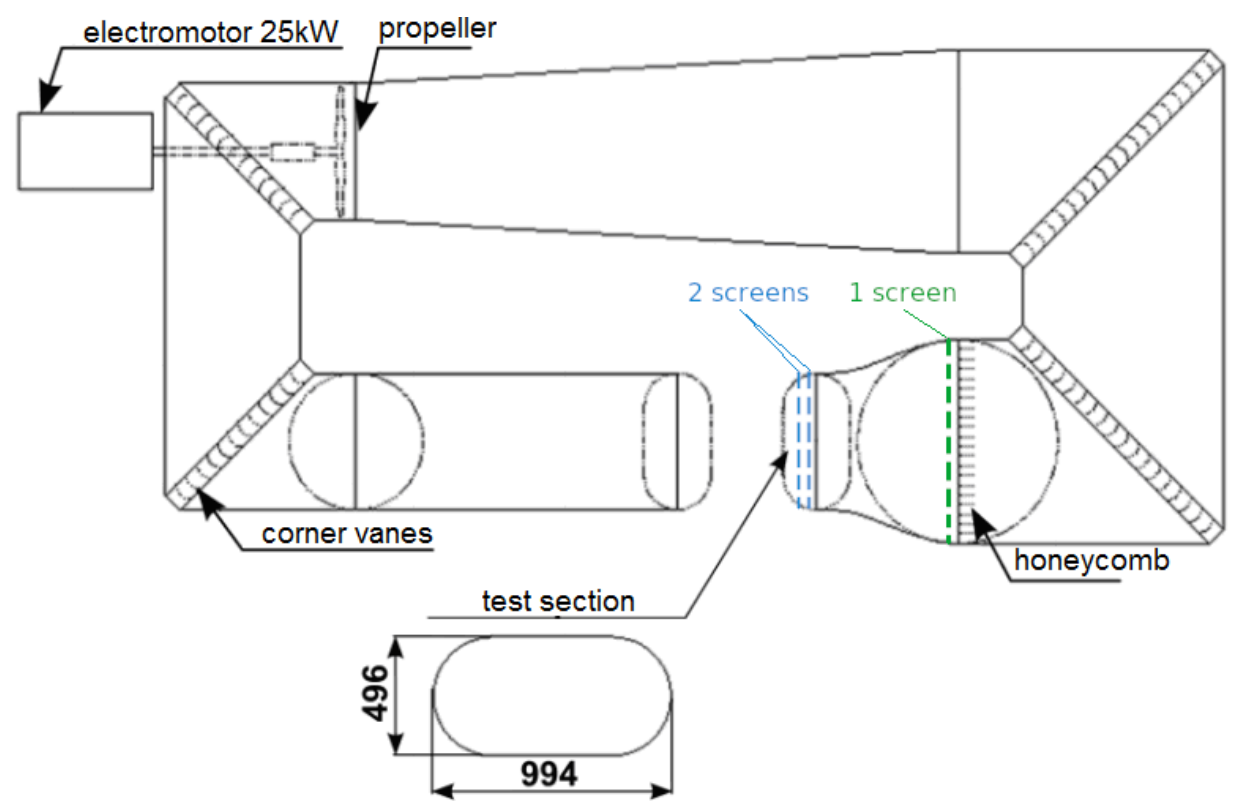

Figure 1 Layout of $1 \times 0.5 \mathrm{~m}$ low speed wind-tunnel of Technical university of Kosice 


\section{SCREENS}

The measured wind tunnel had three configurations:

1. without screens,

2. with one screen in settling chamber,

3. with the same screen in settling chamber and pair of screens in throat of nozzle, at the beginning of the test section.

Parameters of the screen in settling chamber are:

- material: glass fiber

- fiber diameter: $0.16 \mathrm{~mm}$

- fiber spacing : $1.52 \mathrm{~mm}$ x $1.35 \mathrm{~mm}$

- $\sigma: 0.19$

- $\beta: 0.81$

- K0: 0.273 (calculated for $\theta=0$ )

- $\alpha: 0.93$ (applies to small angles $\theta$ )

- Re: $53-320$ (at $5-30 \mathrm{~m} / \mathrm{s}$ )

Parameters of the screens in throat of nozzle are:

- material: aluminium

- wire diameter: $0.22 \mathrm{~mm}$

- wire spacing: $1.177 \mathrm{~mm} \times 1.46 \mathrm{~mm}$

- $\sigma: 0.266$

- $\beta: 0.734$

- K0: 0.445 (calculated for $\theta=0$ )

- $\alpha: 0.89$ (applies to small angles $\theta$ )

- gap between pair of screens: $40 \mathrm{~mm}$

- Re: 73 - 440 (at $5-30 \mathrm{~m} / \mathrm{s}$ )

\section{SPHERE AND ITS SUSPENSION}

The sphere was made from a bowling ball. The same stock was used by Platt in 1936 because of it superior surface finish [4]. The sphere was suspended from the mechanical balance on three steel wires of diameter $0.3 \mathrm{~mm}$. This kind of support was selected because of its simplicity.

The diameter of sphere is $216.4 \mathrm{~mm}$. The deviation of surface from the ideal spherical shape, measured by waviness over the length $50 \mathrm{~mm}$, is at most $60 \mu \mathrm{m}$, only the filling of holes has value 400 $\mu \mathrm{m}$. Before the surface finish the suspension wires were inserted and fixed by a screw cam (Fig. 2, Fig. 3).

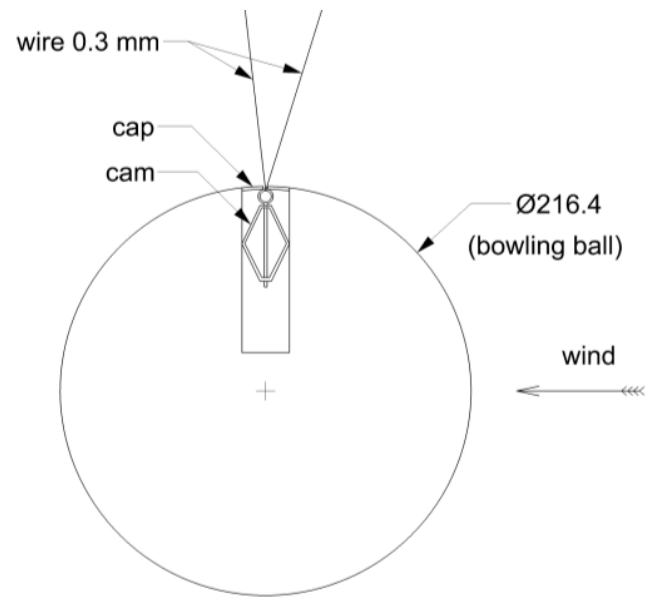

Figure 2 Suspension of sphere in the single point. 
Fig. 2 depicts first version of suspension, where the interference to the flow in boundary layer was restricted to the single point on the surface. All three suspension wires arose from the same point. However, at some wind velocities during the measurement the oscillations developed and the rocking motion caused fatigue break of suspension wire. Then the second version of suspension (Fig. 3) was chosen which prevented oscillation and fatigue. Three long narrow channels were drilled in sphere and suspension wires were inserted into these channels.

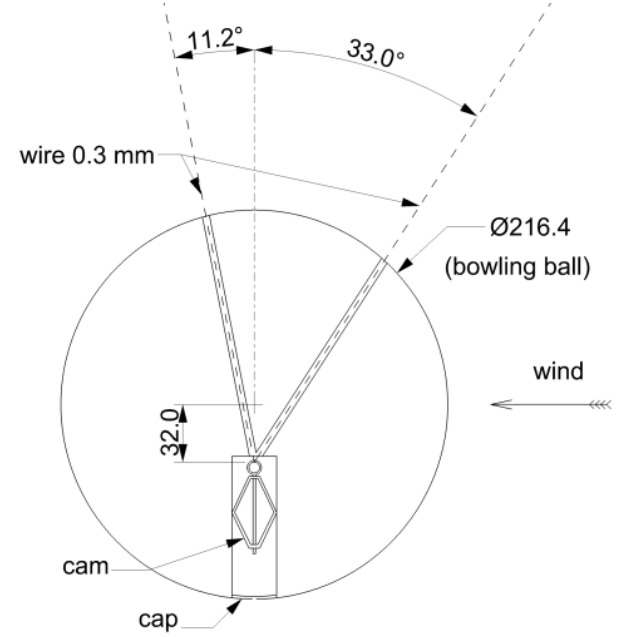

Figure 3 Suspension of sphere in three points.

\section{SLOW HOT-WIRE ANEMOMETER}

Dantec MiniCTA uses rugged but slow hot-wire probe 54T29. Instead of fragile wire of diameter $0.01 \mathrm{~mm}$ or less it uses more robust coil on $\sim 0.5 \mathrm{~mm}$ beam with higher thermal inertia (Fig. 4).

After simulation of step movement acceleration it was found, that the time constant of the probe is less than advertised. Reverse engineered time constant is $\sim 0.045 \mathrm{~s}$ (Fig. 5).

It means that theoretically it can be used to detect dominant frequencies of turbulent eddies at least. With the signal attenuated to $90 \%$ (i.e. $-1 \mathrm{~dB}$ ) it can reconstruct the signal $1.75 \mathrm{~Hz}$. The sampling frequency was chosen at $20 \mathrm{~Hz}$.

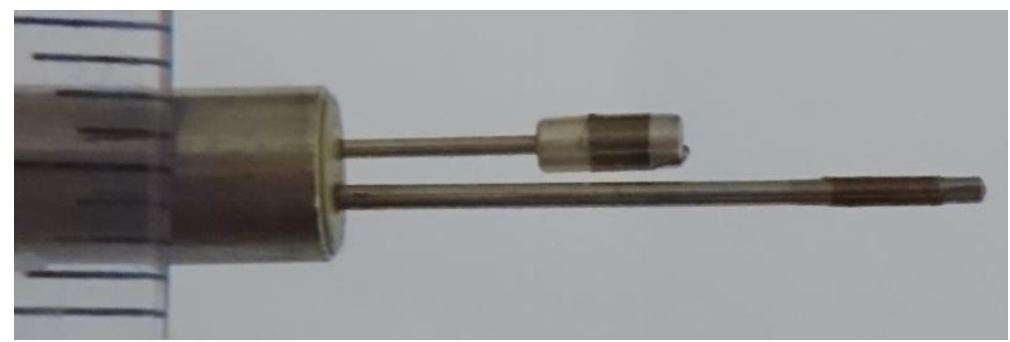

Figure 4 Detail of Dantec 54T29 hot-wire probe. 


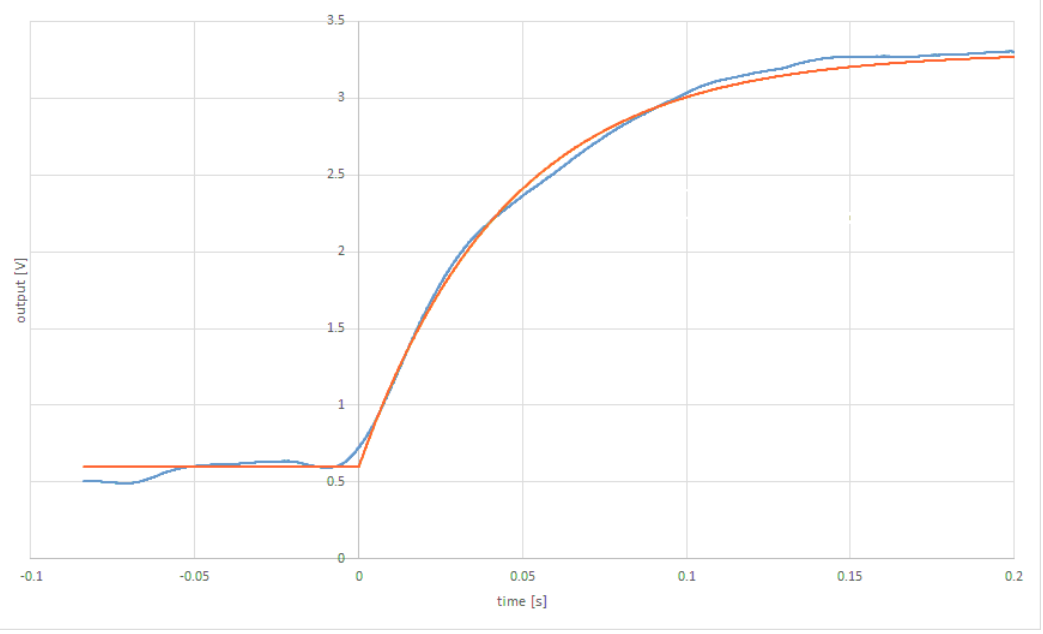

Figure 5 Step response of Dantec 54T29 hot-wire probe (noisy blue curve) and comparison with the stepresponse of the 1st-order dynamic system with time constant of $0.045 \mathrm{~s}$ (red curve).

\section{RESULTS}

Results of CD measurements, with low turbulence examples for comparison, are in the Fig. 6.

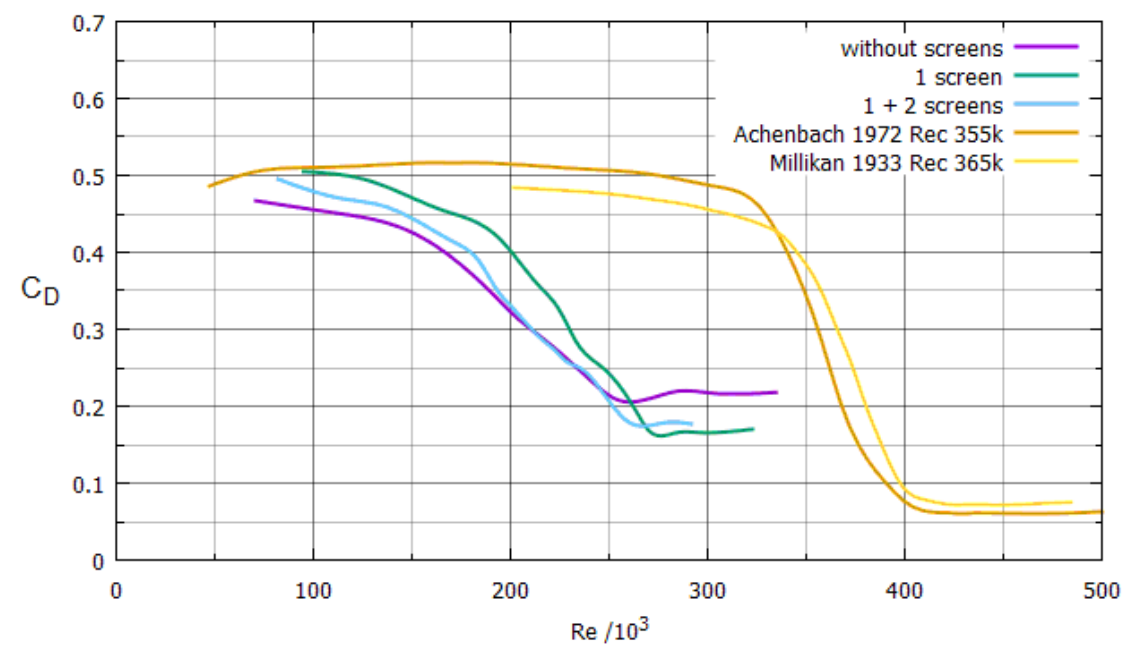

Figure $6 \mathrm{CD}$ of sphere in dependency of Re in three configurations of the wind-tunnel of Technical university in Kosice (without screens, with 1 screen, with both 1 screen and 2 screens) and comparison with measurements in better wind tunnels made by Millikan in 1933[3] and Achenbach in 1972 [9].

In original state, without screens, Recrit $=209400$ and $\mathrm{TF}=1.84$. Corresponding turbulence intensity is $1.03 \%$.

With the screen, Recrit=229 400 and $\mathrm{TF}=1.68$. Corresponding turbulence intensity is $0.85 \%$, it means ration of decrease of turbulence equal to 0.83 . Prediction of the ratio of decrease based on geometry of the screen was between 0.706-0.840 (according Prandtl or Dryden).

The fluctuations measured by Dantec Mini-CTA with the probe $54 \mathrm{~T} 29$ (sampling $20 \mathrm{~Hz}$, time window $7 \mathrm{~s}$ ) give intensity $0.91 \%$ (in original state) and $0.70 \%$ (with one screen). Ratio of decrease is 0.77 . 


\section{CONCLUSION}

The turbulence intensity measured by both methods (sphere and slow CTA) is in good agreement. As can be seen in Fig. 6, only configuration with one screen decreases turbulence. The screens immediately in front of the test section don't improve Recrit and this result was expected. In original state of the wind-tunnel the turbulence intensity is $1.03 \%$. With one screen in settling chamber the turbulence intensity is $0.85 \%$

\section{Acknowledgement}

This work has been supported by the grant APVV-18-0248 project.

\section{References}

[1] L. Prandtl, "Der Luftwiderstand von Kugeln," Nachrichten der Gesellschaft der Wissenschaften zu Göttingen, Mathematisch-physikalische Klasse, pp. 177-190, 1914.

[2] H. L. Dryden and A. M. Kuethe, "Effect of turbulence in wind-tunnel measurements," NACATR-342, 1930.

[3] C. B. Millikan and A. L. Klein, "The Effect of Turbulence: An Investigation of Maximum Lift Coefficient and Turbulence in Wind Tunnels and in Flight," Aircraft Engineering and Aerospace Technology, vol. 5, no. 8, pp. 169-174, 1933.

[4] R. C. Platt, "Turbulence factors of N.A.C.A. wind tunnels as determined by sphere tests," NACA-TR-558, 1936.

[5] G. I. Taylor, "Statistical theory of turbulence: V - Effect of turbulence on boundary layer: Theoretical discussion of relationship between scale of turbulence and critical resistance of spheres," Proc. Roy. Soc. A, vol. 151, no. 888, pp. 307-317, 1936.

[6] R. G. Robinson, "Sphere tests in the N.A.C.A. 8-foot high-speed tunnel," Jour. Aero. Sci., vol. 4, no. 5, pp. 199-201, 1937.

[7] H. L. Dryden, G. B. Schubauer, W. C. Mock, and H. K. Skramstad, "Measurements of Intensity and Scale of Wind-Tunnel Turbulence and Their Relation to the Critical Reynolds Number of Spheres," NACA-TR-581, 1937.

[8] H. L. Dryden, "Turbulence and the Boundary Layer," Jour. Aero. Sci., vol. 6, no. 3, pp. 85-100, 1939.

[9] E. Achenbach, "Experiments on the flow past spheres at very high Reynolds numbers," in: J. Fluid Mech., vol. 54, no. 8, pp. 565-575, 1972. doi:10.1017/S0022112072000874

[10] I. Ganobčík, "Zlepšenie kvality prúdu v aerodynamickom tuneli so sitom," M.S. thesis, Technická univerzita v Košiciach, Slovak Republic, 2019.

[11] J. Pavlinský, M. Spodniak, Z. Zgodavová, and H. Némethová, "Návrh a realizácia modelu krídla určeného pre aerodynamické meranie," in Bezpečnost' a doprava 2018: Teória a prax v bezpečnosti a krízovom riadení v doprave, Brno, Czech Republic, 2018, pp. 382-390.

[12] S. Abu-darag and D. Rozehnal, "Experimental evaluation and set-up of a new apparatus designed for transitional flow experiments," EPJ Web of Conferences, vol. 25, 2012. doi: 10.1051/epjconf/20122501001

[13] F. Heško, P. Lipovský, and R. Bréda, "Aerometrický systém lietadla," in Měření, diagnostika, spolehlivost palubních soustav letadel 2016, Brno, 2016.

[14] P. Gašparovič, K. Semrád, and M. Cúttová, "Properties of Broezel static probe," in Proceedings of the International conference Experimental Fluid Mechanics 2015: November 17.-20., 2015 : Prague, Czech Republic , Praha, 2015, pp. 194-197 doi: 10.1051/epjconf/201611402026 .

[15] P. Gašparovič, "Flat static probe insensitive to yaw," in 29th symposium on anemometry: Proceedings: 2. - 3.6.2015: Holany-Litice , Praha, 2015, pp. 18-20.

[16] P. Gašparovič, "Cheap silicone tubing micromanometer," in 27th symposium on Anemometry, June 4th-5th, 2013, Holany - Litice, Czech Republic, Prague, 2013, pp. 18-21. 
[17] P. Gašparovič and P. Szabó, "Comparison of numeric and exact solution of pressure far flowfield," in New Trends in Aviation Development 2016: Proceedings of the XII. International Scientific Conference: Kosice, September 8 - 9, 2016, 2016, pp. 1-6.

[18] P. Gašparovič, "Convergence of inviscid axial-symmetric flow past sphere," in TechSoft Engineering ANSYS 2015: Setkání uživatelů a konference: Sborník: 27. - 29.5.2015: Hotel Zámek Valeč, Praha, 2015, pp. 1-6.

[19] P. Gasparovic, "Comparison of the exact solution of inviscid flow past sphere with the results of Control volume method and Panel method," in TechSoft Engineering ANSYS 2018: Setkání uživatelu a konference: Sborník: 23-25.5.2018: Harrachov, Česká republika , Praha, 2018, pp. $1-7$.

[20] P. Gašparovič and I. Ganobčík, "Comparison of turbulence measurements in wind tunnel," in 33rd symposium on anemometry: Proceedings: 28-29.5.2019: Holany-Litice , Praha, 2019, pp. $13-17$.

[21] P. Gašparovič, I. Ganobčík, T. Brestovič, M. Hovanec, L. Főzö, "Improvement of wind tunnel flow with screens," in: New Trends in Aviation Development 2019, Danvers (USA), IEEE 2019, pp. 64-67. ISBN 978-1-7281-4078-0

Received 10, 2019, accepted 12,2019

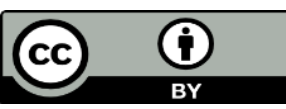

Article is licensed under a Creative Commons Attribution 4.0 International License 